\title{
ASSOCIATION OF BODY MASS INDEX AND LIPID PROFILE WITH CHRONIC HEPATITIS C INFECTION
}

\author{
Amna Younas, Waqas Hanif*, Oshaque Ali*, Sumaira Jamal**, Aqsa Nawaz**, Qurat Ul Ain*** \\ Nishtar Hospital, Multan Pakistan, ${ }^{*}$ Combined Military Hospital Multan/National University of Medical Sciences (NUMS) Pakistan, **University of Agriculture, \\ Faisalabad Pakistan, ${ }^{* * *}$ Armed Forces Institute of Pathology/National University of Medical Sciences (NUMS) Rawalpindi Pakistan
}

\section{ABSTRACT}

Objective: To find out association of lipid profile and body mass index (BMI) profile among cases having chronic hepatitis C virus (CHCV) infection.

Study Design: Cross sectional study.

Place and Duration of Study: Departments of Medicine and Pathology, Combined Military Hospital, Multan Pakistan, from Mar 2019 to Feb 2020.

Methodology: A total of 320 cases of both genders, aged 18-60 years, having chronic hepatitis C virus infection were enrolled. After taking relevant history and physical examination, venous blood sample of each patient was taken and sent to institutional laboratory for analysis of serum total cholesterol (TC) level, serum triglyceride (TG) level, low density lipoprotein (LDL), high density lipoprotein (HDL) were analyzed. Body mass index among all the study participants was also calculated.

Results: Out of a total of 320 cases, there were $152(47.5 \%)$ male and $168(52.5 \%)$ female. Mean age was $41.7 \pm 8.1$ years. Most of the cases, $97(30.3 \%)$ were between 41-50 years of group. Dyslipidemia was noted in $144(45 \%)$ cases. Increasing age and increasing Body mass index were found to have statistical significance with the presence of dyslipidemia $(p$-value $<0.05)$.

Conclusion: Increasing age and body mass index have significant association with dyslipidemia in patients with chronic hepatitis $C$ virus infection. Lipid profile altered among different age and body mass index groups.

Keywords: Body mass index, Chronic hepatitis $C$ virus infection, Lipid profile.

How to Cite This Article: Younas A, Hanif W, Ali O, Jamal S, Nawaz A, Ain QU. Association of Body Mass Index and Lipid Profile with Chronic Hepatitis C Infection. Pak Armed Forces Med J 2021; 71(6): 1985-1988. $\quad$ Doi: https://doi.org/10.51253/pafmj.v6i6.5036

This is an Open Access article distributed under the terms of the Creative Commons Attribution License (https://creativecommons.org/licenses/by-nc/4.0/), which permits unrestricted use, distribution, and reproduction in any medium, provided the original work is properly cited.

\section{INTRODUCTION}

Hepatitis is an important global health problem, especially among developing countries. ${ }^{1}$ Hepatitis is described as inflammation of the liver, mainly caused by hepatitis $B$ virus (HBV) and hepatitis $\mathrm{C}$ virus (HCV) infection. Globally, around 185 million people are affected with HCV infection and it is a major cause of morbidity and mortality. ${ }^{2}$ In general population, prevalence of HCV varies among different geographies and countries, ranging from 1.3-2.9\% while in Pakistan, it is estimated to be around $6.5 \% .^{3}$

Chronic hepatitis $\mathrm{C}$ virus (CHCV) infection is described as non-remission of the disease after testing positive for duration of more than 6 months. It is seen that $70-90 \%$ of the cases having HCV are not able to get spontaneous clearance of the virus in acute phase of the disease and they go on to be chronically infected cases of HCV. ${ }^{4}$ Around 150 million individuals around the world are thought to have $\mathrm{CHCV}$ infection while $\mathrm{CHCV}$ infection is seen to contribute a major chunk in progression to liver cirrhosis and hepatocellular

Correspondence: Dr Waqas Hanif, Department of Pathology, Combined Military Hospital, Multan Pakistan

Received: 18 Aug 2020; revision received: 27 Nov 2020; accepted: 10 Dec 2020 carcinoma $\mathrm{CHCV}$ infection is found to be responsible for $27 \%$ cases of liver cirrhosis and $25 \%$ of liver cancer cases worldwide. ${ }^{5}$

Liver is the main place where formation as well as clearance of lipoproteins is occurring. Liver is receiving fatty acids and cholesterol from the peripheral tissues and diet and then packages those in the form of lipoprotein complexes. ${ }^{6}$ These formed lipoproteins complexes are then released in into circulation. Lipid metabolism is found disturbing when a person is affected by a major liver disease. ${ }^{7}$

A study from USA noted $70.5 \%$ of the patients with $\mathrm{CHCV}$ infection with hyperlipidemia. ${ }^{8}$ Some researchers have depicted that plasma cholesterol levels are declined in $\mathrm{CHCV}$ infection. In patients having $\mathrm{CHCV}$ infection, body mass index (BMI) has been noted to have a significant association with fibrosis index and cirrhosis at the time of presentation. ${ }^{9}$ Previous studies also noted that progression of $\mathrm{CHCV}$ infection is influenced by clinical manifestations of metabolic syndrome. ${ }^{10}$

We did this study with an aim to find out association of lipid profile and body mass index (BMI) profile among cases having $\mathrm{CHCV}$ infection. The results of 
this study might prove useful giving us clue about monitoring and potential management of lipid profile and BMI when cases of $\mathrm{CHCV}$ infection are confronted.

\section{METHODOLOGY}

This cross sectional study was conducted at the departments of Pathology and Medicine, Combined Military Hospital, Multan from March 2019 to February 2020. Approval from Institutional Ethical Committee was taken for this study. Informed written consent was sought from all the participants of this study.

A sample size of 320 was calculated considering a confidence level of $95 \%$, proportion of cases as $70.5 \%$ and 5\% margin of error. ${ }^{11}$ Sample technique was nonprobability consecutive sampling technique.

Inclusion Criteria: Cases of both genders, aged 18-60 years, having $\mathrm{CHCV}$ infection (continuously detectable HCV RNA on qualitative polymerase chain reaction for at least 1 year, as per medical record and investigation reports) and willing to be part of this research were included.

Exclusion Criteria: Patients having acute hepatitis, hypertension, diabetes mellitus, ischaemic heart disease or chronic renal failure were excluded. Patients taking lipid lowering or hepatotoxic drugs were also excluded.Cases having positive hepatitis B surface antigen, hepatocellular carcinoma or with liver transplantation were excluded.

After taking relevant history and physical examination, venous blood sample of each patient was taken and sent to institutional laboratory for analysis of serum total cholesterol (TC) level, serum TG level, LDL, HDL. Dyslipidemia was considered if any one of the following noted: TC $>5.2 \mathrm{mmol} / \mathrm{L}, \mathrm{TG}>1.7 \mathrm{mmol} / \mathrm{L}$. HDL $<1.1 \mathrm{mmol} / \mathrm{L}$ in males and $<1.3 \mathrm{mmol} / \mathrm{L}$ in females or LDL $>3.4 \mathrm{mmol} / \mathrm{L}^{12}$. BMI was calculated by weight in $\mathrm{kg}$ divided by height in meter ${ }^{13}$ of all the study participants. A specialized proforma was designed to handle all the study information.

Statistical Package for the Social Sciences (SPSS) version 23 was used for data analysis. Frequencies and percentages were noted for gender and frequency of dyslipidemia. Mean and standard deviation were estimated regarding age, BMI, duration of $\mathrm{CHCV}$ infection, TC, TG, LDL and HDL levels. Student t-test was used to compare the quantitative variables while chi square test was applied to compare qualitative variables considering $p \leq 0.05$ as statistically significant.

\section{RESULTS}

Out of a total of 320 cases, there were 152 (47.5\%) male and $168(52.5 \%)$ female. Age range was 18-60 years of age whereas overall mean age was $41.7 \pm 8.1$ years. Most of the cases, 97 (30.3\%) were between 41-50 years' age group. Overall, mean BMI was $30.5 \mathrm{~kg} / \mathrm{m}^{2}$ while most of the cases, 167 (52.2\%) had BMI between $25-30 \mathrm{~kg} / \mathrm{m}^{2}$. Dyslipidemia was noted in $144(45 \%)$ cases shown in Table-I.

Table-II shows associationof study characteristics. Age and BMI were noted to have statistical significance with dyslipidemia as increasing age $p=0.005$ as well BMI were found to have statistical significance with the presence of dyslipidemia $(p<0.001)$.

Table-I: Characteristics of Study participants $(n=320)$.

\begin{tabular}{|c|c|c|c|c|}
\hline \multicolumn{3}{|c|}{ Characteristics } & \multicolumn{2}{|c|}{ Frequency (\%) } \\
\hline \multirow{2}{*}{\multicolumn{2}{|c|}{ Gender }} & Male & \multicolumn{2}{|c|}{$152(47.5)$} \\
\hline & & Female & \multicolumn{2}{|c|}{$168(52.5)$} \\
\hline \multirow{4}{*}{\multicolumn{2}{|c|}{ Age (Years) }} & $18-30$ & \multicolumn{2}{|c|}{$58(18.1)$} \\
\hline & & $31-40$ & \multicolumn{2}{|c|}{$79(24.7)$} \\
\hline & & $41-50$ & \multicolumn{2}{|c|}{97 (30.3) } \\
\hline & & $51-60$ & \multicolumn{2}{|c|}{$86(26.9)$} \\
\hline \multirow{3}{*}{$\begin{array}{l}\text { Body Mass } \\
\text { Index } \mathrm{kg} / \mathrm{m}^{2}\end{array}$} & & $<25$ & \multicolumn{2}{|c|}{$65(20.3)$} \\
\hline & & $25-30$ & \multicolumn{2}{|c|}{$167(52.2)$} \\
\hline & & $>30$ & \multicolumn{2}{|c|}{$88(27.5)$} \\
\hline \multirow{2}{*}{\multicolumn{2}{|c|}{ Dyslipidemia }} & Yes & \multicolumn{2}{|c|}{$144(46.5)$} \\
\hline & & No & \multicolumn{2}{|c|}{$176(53.5)$} \\
\hline \multicolumn{5}{|c|}{$\begin{array}{l}\text { Table-II: Association of dyslipidemia with respect to study } \\
\text { variables. }\end{array}$} \\
\hline \multirow{2}{*}{\multicolumn{2}{|c|}{ Age (years) }} & \multicolumn{2}{|c|}{ Dyslipidemia n (\%) } & \multirow[b]{2}{*}{$\begin{array}{c}p- \\
\text { value }\end{array}$} \\
\hline & & $\begin{array}{l}\text { Present } \\
(\mathrm{n}=144)\end{array}$ & $\begin{array}{l}\text { Absent } \\
(n=176)\end{array}$ & \\
\hline \multirow{2}{*}{ Gender } & Male & $66(45.8)$ & $86(48.8)$ & \multirow{2}{*}{0.589} \\
\hline & Female & $78(54.2)$ & $90(51.2)$ & \\
\hline \multirow{4}{*}{$\begin{array}{l}\text { Age } \\
\text { (years) }\end{array}$} & $18-30$ & $18(12.5)$ & $40(22.7)$ & \multirow{4}{*}{0.005} \\
\hline & $31-40$ & $28(19.4)$ & $51(29.0)$ & \\
\hline & $41-50$ & $54(37.5)$ & $43(23.9)$ & \\
\hline & $51-60$ & $44(30.6)$ & $42(23.9)$ & \\
\hline \multirow{3}{*}{$\begin{array}{l}\text { Body Mass } \\
\text { Index } \\
\mathrm{Kg} / \mathrm{m}^{2}\end{array}$} & $<25$ & $26(18.1)$ & $39(22.2)$ & \multirow{3}{*}{$<0.001$} \\
\hline & $25-30$ & $60(41.7)$ & $107(60.8)$ & \\
\hline & $>30$ & $58(40.3)$ & $30(17.0)$ & \\
\hline
\end{tabular}

Table-III shows association of mean lipid profile respect to age and gender. Total cholesterol and triglycerides were significantly high in cases between 41-60 years of age group ( $p$-value $<0.001)$. HDL was significantly low among 41-60 years of age group ( $p$-value $<0.001)$. Female gender was noted to have significantly higher triglyceride levels ( $p$-alue $<0.02$ ).

Table-IV shows association of BMI with age and gender, higher BMI was found to be significantly associated with increasing age $(p$-value $<0.001)$ while 
there was insignificant association of BMI with gender $(p=0.322)$.

\begin{tabular}{|c|c|c|c|}
\hline \multirow[b]{2}{*}{ Lipid Profile } & \multicolumn{2}{|c|}{ Age Mean \pm SD } & \multirow[b]{2}{*}{$\begin{array}{c}p \text { - } \\
\text { value }\end{array}$} \\
\hline & $\begin{array}{c}18-40 \text { years } \\
(n=137)\end{array}$ & $\begin{array}{c}\text { 41-60 years } \\
(n=183)\end{array}$ & \\
\hline $\begin{array}{l}\text { Total Cholesterol } \\
(\text { Mean } \pm \text { SD) } \mathrm{mmol} / \mathrm{L}\end{array}$ & $3.43 \pm 1.9$ & $3.85 \pm 0.99$ & 0.033 \\
\hline $\begin{array}{l}\text { Triglycerides (Mean } \pm \\
\text { SD) mmol/L }\end{array}$ & $1.06 \pm 0.21$ & $1.19 \pm 0.28$ & $<0.001$ \\
\hline $\begin{array}{l}\text { LDL (Mean } \pm \\
\text { SD)mmol/L }\end{array}$ & $2.45 \pm 0.57$ & $2.52 \pm 0.82$ & 0.359 \\
\hline $\begin{array}{l}\text { HDL (Mean } \pm \text { SD) } \\
\mathrm{mmol} / \mathrm{L}\end{array}$ & $1.29 \pm 0.27$ & $1.15 \pm 0.31$ & $<0.001$ \\
\hline \multirow[b]{2}{*}{ Lipid Profile } & \multicolumn{2}{|c|}{ Gender (Mean \pm SD) } & \\
\hline & $\begin{array}{c}\text { Male } \\
(n=152)\end{array}$ & $\begin{array}{l}\text { Female } \\
(n=168)\end{array}$ & $\begin{array}{c}p- \\
\text { value }\end{array}$ \\
\hline $\begin{array}{l}\text { Total Cholesterol } \\
(\text { Mean } \pm \text { SD) } \mathrm{mmol} / \mathrm{L}\end{array}$ & $3.64 \pm 0.92$ & $3.79 \pm 1.05$ & 0.165 \\
\hline $\begin{array}{l}\text { Triglycerides (Mean } \pm \\
\text { SD) mmol/L }\end{array}$ & $1.11 \pm 0.19$ & $1.17 \pm 0.24$ & 0.021 \\
\hline $\begin{array}{l}\text { LDL }(\text { Mean } \pm \text { SD) } \\
\mathrm{mmol} / \mathrm{L}\end{array}$ & $2.42 \pm 0.63$ & $2.52 \pm 0.73$ & 0.221 \\
\hline $\begin{array}{l}\text { HDL (Mean } \pm \text { SD) } \\
\mathrm{mmol} / \mathrm{L}\end{array}$ & $1.21 \pm 0.29$ & $1.16 \pm 0.33$ & 0.199 \\
\hline
\end{tabular}

Table-IV: Association of body mass index with respect to Gender and Age (Highlight).

\begin{tabular}{|c|c|c|c|}
\hline \multirow[b]{2}{*}{$\begin{array}{l}\text { Body Mass } \\
\text { Index, } \mathbf{k g} / \mathbf{m}^{2}\end{array}$} & \multicolumn{2}{|c|}{ Age n (\%) } & \multirow{2}{*}{$\begin{array}{c}p \text { - } \\
\text { value }\end{array}$} \\
\hline & $\begin{array}{c}\begin{array}{c}18-40 \text { Years } \\
(n=137)\end{array} \\
\end{array}$ & $\begin{array}{c}\text { 41-60 Years } \\
(n=183)\end{array}$ & \\
\hline$<25$ & $42(30.7)$ & $23(12.6)$ & \multirow{3}{*}{0.001} \\
\hline $25-30$ & $68(49.6)$ & $99(54.1)$ & \\
\hline$>30$ & $27(19.7)$ & $61(33.3)$ & \\
\hline \multirow[b]{2}{*}{$\begin{array}{l}\text { Body Mass } \\
\text { Index } \mathbf{k g} / \mathrm{m}^{2}\end{array}$} & \multicolumn{2}{|c|}{ Gender $\mathrm{n}(\%)$} & \multirow[b]{2}{*}{$\begin{array}{c}p \text { - } \\
\text { value }\end{array}$} \\
\hline & $\begin{array}{c}\text { Male } \\
(n=152)\end{array}$ & $\begin{array}{l}\text { Female } \\
(n=168)\end{array}$ & \\
\hline$<25$ & $26(17.1)$ & $39(23.2)$ & \multirow{3}{*}{0.322} \\
\hline $25-30$ & $85(55.9)$ & $82(48.8)$ & \\
\hline$>30$ & $41(27)$ & $47(28.0)$ & \\
\hline
\end{tabular}

\section{DISCUSSION}

Liver is known to be the main place hosting synthesis, storage as well as oxidations of lipids and many other types of macromolecules. Lipid metabolism in liver is vital to maintain systemic nutrient's hemostasis. Disturbance in usual lipid metabolism in the liver is a key characteristic of various diseases like diabetes mellitus, alcoholic and non-alcoholic fatty liver disease and viral infections like HCV infection. Chronic liver disease is known to alter the natural lipid metabolism and some researchers have pointed out an association between $\mathrm{CHCV}$ infection and lipid metabolism. ${ }^{14}$

We noted that age and BMI to have significant association with dyslipidemia as increasing age as well
BMI were found to have statistical significance with the presence of dyslipidemia ( $p$-value $<0.05)$. It was also seen in the present work that total cholesterol and triglycerides were significantly high in cases between $41-60$ years of age group ( $p$-value $<0.05$ ). HDL was significantly low among 41-60 years of age group ( $p$-value $<0.05$ ). A study done by Agbecha et $a l,{ }^{15}$ from Nigeria noted significantly low HDL among cases with $\mathrm{CHCV}$ infection. Maggi et al,16 Serfaty et al,17 and Fabris et al,18 noted patients with $\mathrm{CHCV}$ infection to have abnormally low LDL levels. Floris-Moore et al, ${ }^{19}$ as well as Corey noted patients of $\mathrm{CHCV}$ infection to significantly alter cholesterol levels in comparison to controls. Findings of $\mathrm{Li}$ et $a l,{ }^{20}$ were also aligned to what we found where they noted lower HDL levels among cases with CHCV infection. Nogueira et $a l,{ }^{21}$ and Nashaat, ${ }^{22}$ noted regardless of the genotypes, cases with $\mathrm{CHCV}$ were found to have lower serum HDL levels.

In the present work, we also noted significant association between dyslipidemia and increasing age. These findings are consistent with the local published data where the authors noted age more than 41 years to be linked with increased prevalence and disturbances in lipid profile. Same local data also found HCV infection to be positively linked with increasing BMI which again correlates well with the present findings. Kallwitz et al, ${ }^{11}$ observed BMI more than 30 to be linked with histologic progression and cirrhosis among cases having $\mathrm{CHCV}$ infection.

Quite a few underlying mechanisms have been presented for these abnormal lipid metabolisms among cases with $\mathrm{CHCV}$ infection while genotypes do not seem to alter these findings. ${ }^{2}$ Some researchers have described $\mathrm{CHCV}$ infection and its related inflammatory role to contribute to alterations in LDL metabolism, thus affecting atherogenesis. ${ }^{22}$ Earlier researchers have also shown LDL receptor (LDL-R) to have a role to play in the cellular entry of $\mathrm{HCV}$ while some others have postulated that some key components of lipoprotein and cholesterols metabolism are thought to be involved in the initial entry and infection of HCV. HCV life cycle in the liver is also marked to depend upon hepatic cholesterol as well as lipogenesis pathways. Abnormalities in the lipid profile of $\mathrm{CHCV}$ patients can also contribute to hepatic steatosis and deposition of hepatocellular lipid droplets. ${ }^{23}$

\section{LIMITATION OF STUDY}

Our study has few limitations as well. We could not record the viral load of HCV among our study participants. We were also unable to record fasting samples of our study 
participants. Alanine transaminase (ALT) levels were also not noted among the participants of this study. As we did not note findings about treatment or management protocols, we are unable to suggest how much impact management of lipid disorders in patients having $\mathrm{CHCV}$ infection has on the overall outcome of these set of patients.

\section{RECOMMENDATIONS}

Further studies with longer follow ups and better study designs will further help us improving our current understanding of $\mathrm{CHCV}$ infection with lipid profile and related health issues.

\section{CONCLUSION}

Increasing age and body mass index have significant association with dyslipidemia in patients with chronic hepatitis $C$ virus infection. Lipid profile alters among different age and body mass index groups.

\section{Conflict of Interest: None.}

\section{Authors' Contribution}

AY: Sample calculation, WH: Manuscript writing, OA: Data collection, SJ: Data analysis, AN: Sample analysis, QUA: Study design.

\section{REFERENCES}

1. Mahajan R, Midha V, Goyal O, Mehta V, Narang V, Kaur K, et al. Clinical profile of hepatitis $\mathrm{C}$ virus infection in a developing country: India. J Gastroenterol Hepatol 2018; 33(1): 926-933.

2. Shanmugam RP, Balakrishnan S, Varadhan H, Shanmugam V. Prevalence of hepatitis B and hepatitis C infection from a population-based study in Southern India. Eur J Gastroen Hepat 2018; 30(11): 1344-1351.

3. Hanafiah MK, Groeger J, Flaxman AD, Wiersma ST. Global epidemiology of hepatitis $C$ virus infection: new estimates of agespecific antibody to HCV seroprevalence. Hepatol 2013; 57(2): 1333-1342.

4. Petruzziello A, Marigliano S, Loquercio G, Cozzolino A, Cacciapuoti C. Global epidemiology of hepatitis $C$ virus infection: an up-date of the distribution and circulation of hepatitis $C$ virus genotypes. World J Gastroenterol 2016; 22(34): 7824-7840.

5. Cooke GS, Lemoine M, Thursz M, Gore C, Swan T, Kamarulzaman A, et al. Viral hepatitis and the global burden of disease: a need to regroup. J Viral Hepat 2013; 20(1): 600-601.

6. Decock S, Verslype C. Hepatitis C and insulin resis-tance: Mutual interactions. A review. Acta Clin Belg 2007; 62(2): 111-119.

7. Micallef JM, Kaldor JM, Dore GJ. Spontaneous viral clearance following acute hepatitis $C$ infection: a systematic review of longitudinal studies. J Viral Hepat 2006; 13(1): 34-41.

8. Perz JF, Armstrong GL, Farrington LA, Hutin YJ, Bell BP. The contributions of hepatitis $B$ virus and hepatitis $C$ virus infections to cirrhosis and primary liver cancer worldwide. J Hepatol 2006; 45(1): 529-538.
9. Katsuramaki T, Mizuguchi T, Kawamoto M, Yamaguchi K, Meguro M, Nagayama M, et al. Assessment of nutritional status and prediction of postoperative liver function from serum apolioprotein A1 levels with hepatectomy. World J Surg 2006; 30(2): 1886-1891.

10. Murthy GD, Vu K, Venugopal S. Prevalence and treatment of hyperlipidemia in patients with chronic hepatitis $\mathrm{C}$ infection. Eur J Gastroenterol Hepatol 2009; 21(8): 902-907.

11. Kallwitz ER, Layden-Almer J, Dhamija M, Berkes J, Guzman G, Lepe R, et al. Ethnicity and body mass index are associated with hepatitis C presentation and progression. Clin Gastroenterol Hepatol 2010; 8(1): 72-78.

12. Sohail S, Mustafa MI, Shaheen MA, Ali QM, Tariq MS. Dyslipidemia and mean lipid profile in patients with liver cirrhosis. Int J Res Med Sci 2020; 8(5): 1658-1661.

13. Khovidhunkit W, Kim MS, Memon RA, Shigenaga JK, Moser $\mathrm{AH}$, Feingold KR, et al. Effects of infection and inflammation on lipid and lipoprotein metabolism: mechanisms and consequences to the host. J Lipid Res 2004; 45(1): 1169-1196.

14. Tien PC. Hepatitis C virus-associated alterations in lipid and lipoprotein levels: Helpful or harmful to the heart? Clin Infect Dis 2017; 65(4): 566-567.

15. 1Agbecha A, Usoro CA, Etukudo MH. Lipid profile pattern in chronic viral hepatitis C in Makurdi, Nigeria. Muller J Med Sci Res. 2017; 8(1): 36-41.

16. Maggi G, Bottelli R, Gola D, Perricone G, Posca M, Zavaglia C, et al. Serum cholesterol and chronic hepatitis C. Ital J Gastroenterol 1996; 28(2): 436-440.

17. Serfaty L, Andreani T, Giral P, Carbonell N, Chazouillères $\mathrm{O}$, Poupon R, et al. Hepatitis C virus induced hypobetalipoproteinemia: a possible mechanism for steatosis in chronic hepatitis $\mathrm{C}$. J Hepatol 2001; 34(1): 428-434.

18. Fabris C, Federico E, Soardo G, Falleti E, Pirisi M. Blood lipids of patients with chronic hepatitis: differences related to viral etiology. Clin Chim Acta 1997; 26(1): 159-165.

19. Floris-Moore M, Howard AA, Lo Y, Schoenbaum EE, Arnsten $\mathrm{JH}$, Klein RS, et al. Hepatitis C infection is associated with lower lipids and high-sensitivity C-reactive protein in HIV-infected men. AIDS Patient Care STDS 2007; 21(7): 479-491.

20. Li WC, Lee YY, Chen IC, Sun C, Chiu FH, Chuang $\mathrm{CH}$, et al. Association between the hepatitis $\mathrm{B}$ and $\mathrm{C}$ viruses and metabolic diseases in patients stratified by age. Liver Int 2013; 33(8): 11941202.

21. Nogueira CT, Urbaczek AC, Falcoski TO, Isabel TF, Graminha MA, da Costa PI, et al. Influence of the hepatitis $C$ virus on lipid metabolism in chronic infection. J Basic Appl Pharm Sci 2012; 33(4): 63-70.

22. Nashaat EH. Lipid profile among chronic hepatitis C Egyptian patients and its levels pre-and post-treatment. Nat Sci 2010; 8(2): 83-89.

23. Jabeen S, Rasheed A, Jabeen N, Naz SA, Raza A. Prevalence and association of HBV and HCV infection with cardiovascular disease risk factors in a peri-urban population. JPak Med Assoc 2020; 70(1): 58-63. 